\title{
Seroepidemiology of bluetongue in South Bengal
}

\author{
Arkendu Halder ${ }^{1}$, Siddhartha N. Joardar ${ }^{1}$, Devi Prasad Isore ${ }^{1}$, Indranil Samanta ${ }^{1}$, Panchanan Parui ${ }^{2}$, Dhriti Banerjee ${ }^{2}$
} and Chandan Lodh ${ }^{3}$

1. Department of Veterinary Microbiology, West Bengal University of Animal and Fishery Sciences, Kolkata - 700037, West Bengal, India; 2. Diptera Section, Zoological Survey of India, Kolkata - 700059, West Bengal, India;

3. Department of Veterinary Medicine, Ethics and Jurisprudence, West Bengal University of Animal and Fishery Sciences, Kolkata - 700037, West Bengal, India.

Corresponding author: Siddhartha N. Joardar, e-mail: joardar69@gmail.com, AH: arkenduhalder@gmail.com, DPI: deviprasadisore@gmail.com, IS: isamanta76@gmail.com, PP: diptera.zsi@gmail.com, DB: dhritibanerjee@gmail.com, CL: chand_lodh@rediffmail.com

Received: 24-07-2015, Revised: 05-11-2015, Accepted: 14-11-2015, Published online: 02-01-2016

doi: 10.14202/vetworld.2016.1-5 How to cite this article: Halder A, Joardar SN, Isore DP, Samanta I, Parui P, Banerjee D, Lodh C (2016) Seroepidemiologyof bluetongue in South Bengal, Veterinary World 9(1): 1-5.

\begin{abstract}
Aim: With the aim of revealing the epidemiological intricacies of bluetongue (BT) in the southern part of West Bengal state, the present study was undertaken to assess seroprevalence of BT along with identification of the vector of the disease, i.e., Culicoides midges available in the region in their breeding season with conducive environmental factors, if any.

Materials and Methods: A total of 1509 (sheep-504, goat-1005) samples were collected from three different agroclimatic zones of South Bengal viz. new alluvial, red laterite and coastal saline. To detect anti-BT antibodies in the collected serum samples, indirect-enzyme-linked immunosorbent assay (i-ELISA) was performed. Culicoides midges were collected from those agro-climatic zones of South Bengal for species identification. The meteorological parameters, viz. temperature (maximum and minimum), rainfall and relative humidity of three agro-climatic zones of South Bengal were analyzed for the months of July to December during 2010-2013.
\end{abstract}

Results: The overall seropositivity was $33.13 \%$ and $30.24 \%$ in sheep and goat, respectively as assessed by i-ELISA. In South Bengal, the predominant species of Culicoides found were Culicoides schultzei, Culicoides palpifer and Culicoides definitus.

Conclusion: Since virus transmitting species of Culicoides midges could be detected in South Bengal, besides high seropositivity in ruminants, the possibility of circulating BT virus in South Bengal is quite imminent.

Keywords: antibodies, bluetongue, Culicoides sp., enzyme linked immunosorbent assay, South Bengal.

\section{Introduction}

Bluetongue (BT) is an acute, infectious, arthropod-borne viral disease of a wide range of domestic and wild ruminants. The major hosts of BT are sheep and some wild ruminants. Cattle, goat and some other wild ruminants show the disease subclinically [1]. BT is the member of genus Orbivirus of the family Reoviridae [2].The epizootics of the disease depend on the complex interaction of host, vector (Culicodes midges) and virus [3].

In the eastern part of India, the incidence of BT is not detected so far unlike southern and western parts $[4,5]$. However, anti-BT antibodies could be detected in sheep, goat, and cattle population of one of the eastern Indian state, West Bengal [6]. Detection of anti-BT antibodies in the host is the indirect evidence of the presence of virus in that specific geographical region [7]. West Bengal state is divided into six

Copyright: Halder et al. Open Access. This article is distributed under the terms of the Creative Commons Attribution 4.0 International License (http://creativecommons.org/licenses/by/4.0/), which permits unrestricted use, distribution, and reproduction in any medium, provided you give appropriate credit to the original author(s) and the source, provide a link to the Creative Commons license, and indicate if changes were made. The Creative Commons Public Domain Dedication waiver (http://creativecommons.org/ publicdomain/zero/1.0/) applies to the data made available in this article, unless otherwise stated. different agro-climatic zones viz. hilly, tarai, old alluvial, new alluvial, red laterite and coastal saline.

In this present study, the southern part of the river Ganga and that of the state (known as South Bengal, Figure-1) which comprises three agroclimatic zones viz. New Alluvial, Red Laterite and Coastal Saline were considered for serum sample collection. To reveal the epidemiological intricacies of BT in the region, the present study was undertaken to assess seroprevalence of BT along with identification of the vector of the disease, i.e. Culicoides midges available in the region in their breeding season with conducive environmental factors, if any, in a holistic manner that has not been done in any earlier study.

\section{Materials and Methods}

\section{Ethical approval}

As per CPCSEA guidelines, study involving clinical samples does not require approval of Institute Animal Ethics Committee. However, samples were collected as per standard sample collection methods without any harm or stress to the animals.

\section{Serum samples}

Blood samples without anti-coagulant were collected from suspected animals, viz. sheep and goat of the targeted agro-climatic zones during the month 
of July to December, from 2010 to 2013. A total of 1509 (sheep-504, goat-1005) samples were collected from three different agro-climatic zones viz. new alluvial, red laterite and coastal saline of South Bengal (Table-1). Sera were separated and stored at $-20^{\circ} \mathrm{C}$. Serum samples were screened by indirect-enzyme-linked immunosorbent assay (i-ELISA) for detecting anti-BT antibodies.

\section{i-ELISA}

To detect anti-BT antibodies in the collected serum samples, i-ELISA was done using i-ELISA kit, procured from the eastern regional collaborating center of All India Network Programme on BT (AINP-BT, Kolkata center) of Indian Council of Agricultural Research. The test was performed as per Joardar et al. [5]. Reading was taken in an ELISA plate reader (ECIL, India) at $492 \mathrm{~nm}$. The average optical density value of negative control was calculated and compared with the test samples.

\section{Culicoides vector}

Culicoides midges were collected from three agro-climatic zones of West Bengal (red laterite, coastal saline and new alluvial) for species identification. The midges were collected during the months

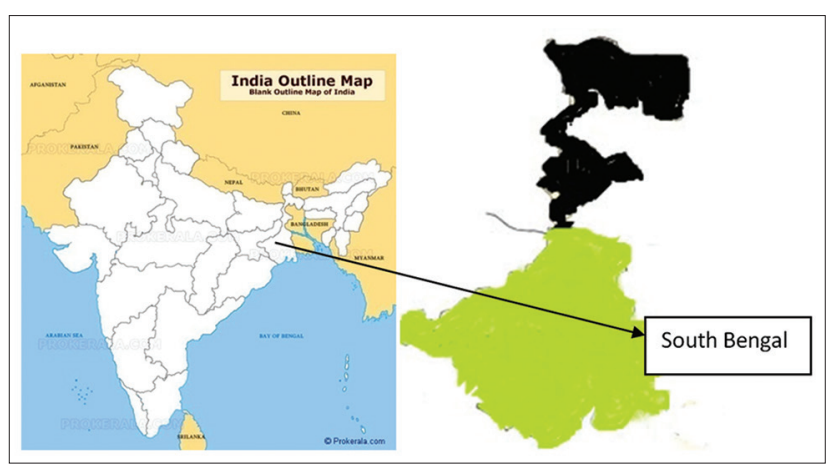

Figure-1: Study area- South Bengal (southern part of West Bengal state) depicted as green color.

Table-1: Serum samples collected from different agro-climatic zones of West Bengal during July, 2010-December, 2013.

\begin{tabular}{llc}
\hline $\begin{array}{l}\text { Agroclimatic } \\
\text { zone }\end{array}$ & $\begin{array}{l}\text { Animal } \\
\text { species }\end{array}$ & $\begin{array}{c}\text { Number of } \\
\text { samples }\end{array}$ \\
\hline New alluvial & Sheep & 122 \\
Red laterite & Goat & 332 \\
& Sheep & 250 \\
Coastal saline & Goat & 120 \\
& Sheep & 132 \\
& Goat & 120 \\
\hline
\end{tabular}

covering post-monsoon to the winter season in the region as the number and activity of Culicoides midges remains rampant at that time. The midges were trapped in the early evening, sorted out and stored in ethanol until used for identification.

\section{Identification of Culicoides midges}

Midges of Culicoides species were identified based on morphological characteristics [8,9].

\section{Metereological parameters}

The meteorological parameters, viz. temperature (maximum and minimum), rainfall and relative humidity of three agro-climatic zones of South Bengal were collected from Regional Meteorological Center, Alipore, Kolkata for the months of July to December during 2010-2013 and analyzed to assess whether conducive environment exists in South Bengal for the propagation of Culicoides midges or not.

\section{Results}

\section{Assessment of sheep serum samples by i-ELISA}

When the sheep sera were assessed by i-ELISA, it was found that out of 504 samples, 167 samples were positive in i-ELISA. The overall seropositivity was $33.13 \%$. The detail of the result is given in Table- 2 .

\section{Assessment of goat serum samples by i-ELISA}

When i-ELISA was done with the serum samples collected from goat, it was found that out of 1005 samples, 304 samples $(30.24 \%)$ were positive. The detail result of i-ELISA is given in Table-3.

\section{Identification of Culicoides midges}

Culicoides midges those were collected from different parts of South Bengal were identified up to species level based on morphological characteristics. The midges were medium sized flies with moderately hairy wings with numerous distinct pale spots including a pale spot over $\mathrm{r}-\mathrm{m}$ crossvein almost on the center of the vein. Radial cells were absent; anterior border of wing with two dark spots, one at the tip of radial vein forming the stigma, other at about the middle of cell R5. Aedaegus was prominent with saddle-shaped stem. Paramere was broad at the base, curved and tapered toward the tip with apical hairs. The identification results are given in Table-4.

\section{Metereological parameters}

Temperature (maximum and minimum), rainfall and relative humidity of three agro-climatic zones were collected and analyzed to know the

Table-2: Assessment of sheep serum samples by i-ELISA to detect anti-bluetongue antibodies.

\begin{tabular}{lcccc}
\hline $\begin{array}{c}\text { Agro-climatic } \\
\text { zone }\end{array}$ & $\begin{array}{c}\text { Number of sample } \\
\text { collected }\end{array}$ & $\begin{array}{c}\text { Number of positive } \\
\text { samples }\end{array}$ & $\begin{array}{c}\text { Number of negative } \\
\text { samples }\end{array}$ & $\%$ positivity \\
\hline New alluvial & 122 & 48 & 74 & 39.34 \\
Red laterite & 250 & 79 & 171 & 31.60 \\
Coastal saline & 132 & 40 & 92 & 30.30 \\
Total & 504 & 167 & 337 & 33.13 \\
\hline
\end{tabular}

ELISA: Enzyme linked immunosorbent assay 
environmental condition of South Bengal at the collection time (Table-5). Maximum temperature varied from 31 to $38^{\circ} \mathrm{C}$ and minimum temperature varied in between 12 and $24^{\circ} \mathrm{C}$. Relative humidity ranged from $72 \%$ to $86 \%$ and average rainfall varied within therange of 4-307 $\mathrm{mm}$.

\section{Discussion}

With the aim of exploring the BT epidemiology in South Bengal, attempts were made to correlate the presence of anti-BT antibodies in small ruminants (sheep and goat) of different agro-climatic zones along with the prevalence of Culicoides midges in those areas.

In the present study conducted during 20102013, when sheep sera were assessed by i-ELISA, it was found that $33.13 \%$ serum samples possessed anti-BT antibodies. In the case of goat, the percentage was 30.24. In one earlier study, similar seropositivity $(34.47 \%)$ was reported in sheep of South Bengal [10]. However, lower \% positivity in goat $(24.03 \%)$ and cattle $(16.21 \%)$ were observed in the same study. Considerable low seropositivity $(2.69 \%$ and $2.13 \%)$ was reported in ruminants of Central Iran and Southeast Iran, respectively $[11,12]$.

New alluvial, red laterite and coastal saline zones of West Bengal were taken into consideration and the seroprevalence detected in sheep were $39.34 \%, 31.60 \%$ and $30.30 \%$, respectively. The seroprevalence ranged from $30 \%$ to $40 \%$ in different zones that indicates the prevalence of the virus in all those agro-climatic zones of West Bengal. Earlier, comparable seroprevalence (overall 42.31\%) was reported in Andhra Pradesh [13]. However, the present report does not corroborate with the results of south Indian states. An overall $71.43 \%$ seroprevalencewas observed in three states of South India, with

Table-3: Assessment of goat serum samples by i-ELISA to detect anti-bluetongue antibodies.

\begin{tabular}{lccc}
\hline $\begin{array}{l}\text { Agro-climatic } \\
\text { zone }\end{array}$ & $\begin{array}{c}\text { Number of } \\
\text { samples } \\
\text { collected }\end{array}$ & $\begin{array}{c}\text { Number } \\
\text { of positive } \\
\text { samples }\end{array}$ & \% positivity \\
\hline New alluvial & 332 & 137 & 41.26 \\
Red laterite & 553 & 120 & 21.69 \\
Coastal saline & 120 & 47 & 37.16 \\
Total & 1005 & 304 & 30.24 \\
\hline
\end{tabular}

ELISA: Enzyme linked immunosorbent assay
65.19\% in Andhra Pradesh, 79.5\% in Karnataka and $80.95 \%$ prevalence in Tamil Nadu using competitive ELISA (cELISA) [14]. However, low seroprevalence $(9.3 \%)$ was reported in ruminants of Kerala [15].

In this study, $33.13 \%$ seroprevalence was observed in sheep. Though, a much higher $(87 \%)$ report of seroprevalance from Tamil Nadu [16] and a much lower (23.5\%) report from Haryana, Himachal Pradesh and Punjab [17] were also observed. In Maharashtra state, $40.36 \%$ seropositivity was reported in 2006 [18]. In sheep, $36.11 \%$ and $30.3 \%$ seropositivitywere reported from Gujarat in 2004 [19] and 2005 [20], respectively. Shlash Khalid et al. [21] found $43.97 \%$ seropositivity in sheep of Iraq using cELISA.

The overall seropositivity in goat was nearly equal to sheep which is in opposite with earlier findings [22]. Goats, though refractorymay be an unapparent host to the virus and an important link in the epidemiology of the disease [23]. In India, most sheep are grazed and housed with goats and the implications of these mixed flocks on the epidemiology and control of the disease are profound and need to be investigated in more detail [24].

In another recent study, when total 364 animal sera (sheep-120, goat-112, cattle-132) were screened by i-ELISA, 32 of sheep $(26.66 \%), 35$ of goat $(31.25 \%)$, and $69(52.27 \%)$ of cattle samples were found positive, though no outbreak or incidence of BT in animals of Orissa being reported so far [25]. The percent positivity of sheep and goat serum collected from Orissa was similar with the values of serum samples collected in the present study in South Bengal. Surprisingly, no outbreak occurred in this state though a considerable number of small ruminants show high titer of anti-BT antibodies.

Culicoides midges were collected from different agro-climatic zones of South Bengal and identification upto species level was carried out. Culicoides species identified from three agro-climatic zones (new alluvial, red laterite and coastal saline) were Culicoides schultzei, Culicoides palpifer, and Culicoides definitus. However, in an earlier study Culicoides actoni, Culicoides clavipalpis, Culicoides oxystoma, Culicoides anopheles, C. palpifer and Culicoides alatus were identified belonged to certain agro-climatic zones of West Bengal [26]. In Indonesia during 1993, serotype 21 of BT virus was isolated

Table-4: Identification of Culicoides species from different areas of South Bengal.

\begin{tabular}{llll}
\hline Area of collection & Agro-climatic zone & Month of collection & Species identified \\
\hline Khatra (District-Bankura) & Red laterite & April & C. schultzei \\
Belgachia (District-Kolkata) & New alluvial & November & C. schultzei, C. palpifer, C. definitus \\
Agarpara (District-North 24 pgs) & New alluvial & December & C. schultzei \\
Kamarhati (District-North 24 pgs) & New alluvial & January & C. schultzei \\
Sandeshkhali (District-North24 pgs) & Coastal saline & January & C. schultzei \\
Patelnagar (Disttict-Birbhum) & Red latterite & August & C. schultzei \\
Hariharpara (District-Murshidabad) & New alluvial & November & C. schultzei \\
Malda town (District-Malda) & New alluvial & & C. schultzei \\
\hline
\end{tabular}

C. schultzei: Culicoides schultzei, C. palpifer: Culicoides palpifer, C. definitus: Culicoides definitus 
Table-5:Meteorological parameters of the study areas (agro-climatic zones) during collection period (July, 2010- December, 2013).

\begin{tabular}{llcc}
\hline $\begin{array}{l}\text { Agro-climatic } \\
\text { zone }\end{array}$ & $\begin{array}{l}\text { Temperature } \\
\left({ }^{\circ} \mathbf{C}\right)\end{array}$ & $\begin{array}{c}\text { Relative } \\
\text { humidity } \\
\mathbf{( \% )}\end{array}$ & $\begin{array}{c}\text { Rainfall } \\
(\mathbf{m m})\end{array}$ \\
\hline New alluvial & $\begin{array}{l}\text { Maximum-32 } \\
\text { Minimum -12 }\end{array}$ & $72-85$ & $4-250$ \\
Red laterite & $\begin{array}{l}\text { Maximum -38 } \\
\text { Minimum -24 }\end{array}$ & $73-86$ & $55-276$ \\
Coastal saline & $\begin{array}{l}\text { Maximum -31 } \\
\text { Minimum -12 }\end{array}$ & $80-86$ & $8-307$ \\
\hline
\end{tabular}

from C. palpifer [27]. Culicoides brevitarsis Keiffer and $C$. imicola Keiffer are proven vectors of BT virus (BTV), occurring widely in India [28]. Recently, BTV (serotype-16) could be isolated from C. schultzei trapped from Kamarhati area (24 pgs District of South Bengal) [29]. The C. schultzei complex contains several species viz. C. oxystoma, C. schultzei, Culicoides subschultzei, Culicoides kingi, Culicoides rhizophorensis, Culicoides enderleini, Culicoides nevilli and Culicoides neoschultzei $[30,31]$ having very less morphological differences. Of these midges, C. oxystoma and $C$. schultzei were proven as potential vectors for BTV and epizootic hemorrhagic disease virus responsible for transmitting the virus among different groups of animals [32].

In new alluvial region, the average maximum temperature was more than $25^{\circ} \mathrm{C}$, except the month of December. In the case of red laterite area, the average maximum temperature was more than $28^{\circ} \mathrm{C}$ and in thecoastal saline region it was more than $30^{\circ} \mathrm{C}$ except the month of December when maximum temperature was $25^{\circ} \mathrm{C}$. It is an established fact that the spread of BTVis closely related with air temperature; atemperature between 19 and $32^{\circ} \mathrm{C}$ being most conducive for transmission. Temperature below $9^{\circ} \mathrm{C}$ inhibits the virus replication, depending on the strain of virus concerned [33]. It was also noticed that at a higher temperature, a greater proportion of Culicoides midges would be competent to transmit BTV and some refractory species of Culicoides (C. nubeculosis) become competent in favorable atmospheric condition [34]. From the data shown in Table-5, it is clear that the atmospheric temperature in those three agro-climatic zones favors the replication of the virus in the vector. The relative humidity of those agro-climatic zones varied from $73 \%$ to $86 \%$. The relative humidity required for propagation of midges is more than $80 \%$. Hence, it can be inferred that the environmental parameters are quite conducive for the propagation of the vectors in South Bengal.

\section{Conclusion}

As virus transmitting species of Culicoides midges could be detected in South Bengal, besides high seropositivity in ruminants, the possibility of circulating BTV in South Bengal cannot be ruled out. As such to avoid the menace of BT outbreaks, more surveillance of the disease incidence should be encouraged and general preparedness to counter outbreaks is advocated.

\section{Authors' Contributions}

Collection of serum samples, screening of samples by ELISA and collection of Culicoides midges were done by $\mathrm{AH}$. The midges were identified by PP and DB. The entire work was done under the supervision of SNJ. Data were analyzed by SNJ and CL. The manuscript was prepared by $\mathrm{AH}$ and correction/ modifications were done by DPI and IS. All authors read and approved the final manuscript.

\section{Acknowledgments}

This work was financially supported by the grant (F.N. 3(8)/98 ASR-IV dated 23.3.2001) of All India Network Programme on BT (Indian Council of Animal Research). We are grateful to the Vice-Chancellor, W.B.U.A.F.S, Belgachia, Kolkata for providing the research facilities.

\section{Competing Interests}

The authors declare that they have no competing interests.

\section{References}

1. Maclachlan, N.J. and Dubovi, E.J. (2011) Fenner's Veterinary Virology. Academic Press, London. p283.

2. Yasothai, R. (2013) Report on outbreak of bluetongue in Erode district of Tamil Nadu. Int. J. Sci. Environ. Technol., 2:646-648.

3. Boyle, D.B., Bulach, D.M., Mathew, A.R., Adams, M.M., Walker, P.J. and Weir, R. (2012) Genomic sequences of Australian bluetongue virus prototype serotypes reveal global relationships and possible routes of entry into Australia. J. Virol., 86:6724-6731.

4. Joardar, S.N., Lodh, C., Chakrabarti, A., Baksi, S. and Aich, R. (2009) Isolation of bluetongue virus serotypes 15 and 21 in West Bengal, India. Vet. Rec., 165: 751-752.

5. Joardar, S.N., Barkataki, B., Halder, A., Lodh, C. and Sarma, D. (2013) Seroprevalence of bluetongue in North Eastern Indian state-Assam. Vet. World, 6(4): 196-199.

6. Biswas, M., Joardar, S.N., Samanta, I., Isore, D.P. and Aich, R. (2009) Seroprevalence of bluetongue in different species of animals in West Bengal: Present scenario. Indian J. Anim. Health, 48(1): 43-46.

7. Joardar, S.N., Mukherjee, S., Lodh, C., Halder, A. and Mukherjee, A. (2015) Seroprevalence of bluetongue in free range mithuns (Bos frontalis). Adv. Anim. Vet. Sci., 3(9):500-502.

8. Dagupta, S.K. (1995) Morphotaxonomic features and species of Indian Culicoides. (Diptera: Ceratopogonidae). In: Prasad, G. and Srivastava, R.N., editors. Bluetongue: Indian Perspective. HAU Press, Hisar, India. p115-188.

9. Kim, H.C., Glenn, A.B., Myung-Soon, K., Terry, A.K., Sung-Tae, C. and Jee-Yong, P. (2014) Seasonal abundance of Culicoides (Diptera: Ceratopogonidae) collected by mosquito magnet $^{\circledR}$ in Northern Gyeonggi-do (Province), Korea. Korean J. Parasitol., 52: 57-62.

10. Chakrabarti, A., Lodh, C., Joardar, S.N. and Aich, R. (2007) Seroprevalence of bluetongue in West Bengal-current status. Indian J. Comp. Microbiol. Immunol. Infect. Dis., 28:63-64.

11. Noaman, V., Shirvani, E., Hosseini, S.M., Shahmoradi, A.H., Heideri, M.R., Raiszade, H., Kamalzade, M. and Bahreyari, M. (2013) Serological 
surveillance of bluetongue virus in central Iran. Vet. Ital., 49(2): 141-144.

12. Mozaffari, A.A., Khalili, M. and Yahyazadeh, F. (2012) A serological investigation of bluetongue virus in cattle of South-East Iran. Vet. Ital., 48(1): 41-44.

13. Sreenivasulu, D. and SubbaRao, M.V. (1999) Seroepidemiology of bluetongue disease in Andhra Pradesh. Indian J. Anim. Sci.,69: 292-294.

14. Dayakar, S., Sreenivasulu, D., Sudharani, K., SubbaRao, M.V. and Sreenivasulu, P. (2001) Serological survey for the prevalence of bluetongue virus antibodies in cattle by competitive enzyme linked immunosorbent assay. Indian J. Anim. Sci.,71(7): 614-616.

15. Arun, S., John, K., Ravishankar, C., Mini, M., Ravindran, R. and Prejit, N. (2013) Seroprevalence of bluetongue among domestic ruminants in Northern Kerala, India. Trop. Biomed., 31: 26-30.

16. Prabhakar, T.G., Meenambigai, T.V., Govindarajan, R., Daniel Joy Chandran, N. and Koteeswaran, A. (2005) Comparative efficacy of competitive ELISA over AGID for detection of bluetongue virus antibodies. Indian J. Comp. Microbiol. Immunol. Infect. Dis., 26: 40-41.

17. Naresh, A. and Prasad, G. (1995) Relative superiority of cELISA for detection of bluetongue virus antibodies. Indian J. Exp. Biol., 33: 880-882.

18. Waghmare, S.G. and Deshmukh, V.V. (2006) Seroepidemiology of bluetongue disease in Maharashtra State. In: Proceedings of National Seminar on Strategies for Control of Bluetongue. p39.

19. Chauhan, H.C., Chandel, B.S., Vasava, K.A., Patel, A.R., Singh, N.M. and Kher, H.N. (2004) Seroprevalence of bluetongue in Gujarat. Indian J. Comp. Microbiol. Immunol. Infect. Dis., 25: 80-83.

20. Shringi, S. and Shringi, B.N. (2005) Comparative efficacy of AGID, CCIE and competitive ELISA for detecting bluetongue virus antibodies in indigenous breed of sheep and goats in Rajasthan. J. Vet. Sci., 6: 77-79.

21. Shlash Khalid, H., Laith, M.S., Abdul-Rasoul, M.M., Naji, M. and Hussain, H. (2012) Seroprevalence of bluetongue in Iraque. In: Proceedings Eleventh Veterinary Science,Conference. p89-94.

22. Govindarajan, R., Venadabady, N., Prabhakar, T.G., Albert, A. and Koteeswaran, A. (2002) Seroprevalence of bluetongue in Tamil Nadu. Cherion, 31: 99-100.
23. Adam, I.A., Abdalla, M.A., Mohamed, M.E.H. and Aradaib, I.E. (2014) Prevalence of bluetongue virus infection andassociated risk factors among cattle in North Kordufan State, Western Sudan. BMC Vet. Res., 10: 94.

24. Dubey, S.C., Mohan Rao, T.R., Srivastava, C.P., Lonkar, P.S. and Maru, A. (1988) Seroprevalence of bluetongue disease in Rajasthan. Indian J. Anim. Sci., 58: 66-68.

25. Joardar, S.N., Halder, A., Maity, A., Mishra, S.K. and Lodh, C. (2014) Seroprevalence of bluetongue in ruminants of Orissa. Indian J. Comp. Microbiol. Immunol. Infect. Dis., 35(2): 1-3.

26. Biswas, M., Joardar, S.N., Samanta, I., Isore, D.P., Aich, R. and Parui, P. (2011) Conductive environment for propagation of potent bluetongue vector exist in West Bengal. Indian J. Anim. Health, 50(2):46-48.

27. Sendow, S., Soleha, E., Erasmus, B.J. and Daniels. P.W. (1993) Isolation of bluetongue virus serotype 21 from Culicoides spp. In Indonesia. Vet. Microbiol., 36:349-353.

28. Ilango, K. (2006) Bluetongue virus outbreak in Tamil Nadu, southern India: Need to study the Indian biting midge vectors, Culicoides Latreille (Diptera: Ceratopogonidae). Curr. Sci., 90: 163-167.

29. Halder, A., Joardar, S.N., Parui, P., Banerjee, D., Kumar, V., Samanta, I. and Lodh. C. (2013) Prevalence of midges: Potent vectors for bluetongue virus infection in West Bengal, India. Adv. Anim. Vet. Sci.,1(4S): 45-50.

30. Boorman, J. (1989) Culicoides (Diptera: Ceratopogonidae) of the Arabian peninsula with notes on their medical and veterinary importance. Fauna Saudi Arabia, 10:160-224.

31. Cornet, M. and Brunhes, J. (1994) Revision des especes de Culicoides apparentees a C. schultzei (Enderlin, 1908) dans la region afrotropicale (Diptera, Ceratopogonidae). Bull. Soc. Entomol. Fr., 99: 149-164.

32. Mellor, P.S., Osborne, R. and Jennings, D.M. (1984) Isolation of bluetongue and related viruses from Culicoides spp. in the Sudan. J. Hygiene (London), 93: 621-628.

33. Nicoletti, M., Murugan, K. and Serrone, D.P. (2014) Current mosquito-borne disease emergencies in Italy and climate changes. The neem opportunity.Trends Vector Res. Parasitol., 1: 2.

34. Wittmann, E.J. and Baylis, M. (2000) Climate change: Effects on Culicoides-transmitted viruses and implications for the UK. Vet. J., 160: 107-117. 